\title{
PROGRAM DAUR ULANG LIMBAH KAIN PERCA DI DESA MUNGGUGIANTI, GRESIK, JAWA TIMUR
}

\author{
Auditia Setiobudi ${ }^{1}$, Anastasia Filiana Ismawati ${ }^{*}$, Wendra Hartono ${ }^{3}$ \\ ${ }^{1}$ Fakultas Manajemen dan Bisnis, Universitas Ciputra, Surabaya, Indonesia \\ *Email : anastasia.filiana@ciputra.ac.id
}

\begin{abstract}
Informasi Artikel Abstrak
Kata kunci:

Limbah rumah tangga,

Kain perca,

Pola,

Quilting

Diterima: 19-05-2021

Disetujui: 24-06-2021

Dipublikasikan: 14-07-

2021

Limbah rumah tangga yang banyak dan beragam dapat menyebabkan masalah lingkungan. Pengurangan limbah dapat dilakukan dengan program daur ulang, salah satunya dengan mengolah limbah kain sisa atau bahan kain perca. Kegiatan pengabdian kepada masyarakat dapat me mberikan solusi bersama mengenai masalah sosial dan dampak lingkungan yang dapat terjadi. Pemanfaatan produk limbah dengan proses yang sederhana dan bahan yang tersedia merupakan satu peluang pengembangan usaha. Modal yang terbatas namun memiliki nilai jual yang tinggi dapat membantu peningkatan ekonomi masyarakat. Peserta kegiatan Program Daur Ulang Limbah Kain Perca di Desa Munggugianti, Gresik, Jawa Timur adalah perwakilan dari tiap rukun tetangga sebanyak 11 orang warga desa Munggugianti dengan tiga narasumber yang sesuai dengan kepakarannya. Hasil pelatihan kegiatan pengabdian kepada masyarakat ini adalah pengenalan dan demonstrasi proses membuat pola dan menjahit dengan metode quilting. Hasil proses lanjutan kegiatan ini adalah pembuatan produk/ prototype produk dengan bahan dasar kain perca. Bentuk luaran yang dihasilkan diantaranya adalah tas, dompet dan sarung bantal.
\end{abstract}

\section{Keywords :}

Household waste,

Patchwork,

Pattern,

Quilting

\section{Abstract}

Many and various household wastes can cause environmental problems. Waste reduction can be done through a recycling program, one of which is by processing waste cloth or patchwork. Community service activities can provide joint solutions regarding social problems and environmental impacts that can occur. Utilization of waste products with a simple process and available materials is an opportunity for business development. Limited capital but has a high selling value can help improve the community's economy. Participants of the Patchwork Waste Recycling Program in Munggugianti Village, Gresik, East Java are representatives from each neighborhood unit as many as 11 residents of Munggugianti village with three resource persons according to their expertise. The result of this community service activity training is the introduction and demonstration of the process of making patterns and sewing with the quilting method. The result of the follow-up process of this activity is the manufacture of a product/product prototype with the basic material of patchwork. The resulting output forms include bags, wallets and pillowcases. 


\section{PENDAHULUAN}

Sampah atau limbah merupakan salah satu permasalahan yang selalu menjadi perhatian. Barang bekas, sampah, maupun limbah rumah tangga dapat menjadi barang yang berguna bila dapat diolah menjadi suatu barang kerajinan yang unik dan bermanfaat. Limbah rumah tangga seperti kayu bekas, kaleng bekas maupun kain perca sisa dapat menjadi suatu pilihan bahan yang dapat diolah. Limbah kain perca sisa merupakan salah satu jenis limbah yang sulit diolah karena merupakan limbah anorganik yang tidak mudah terurai sehingga tidak dapat dikompos, jika limbah kain diolah dengan cara pembakaran akan menimbulkan asap dan gas beracun yang juga membahayakan lingkungan.

Limbah yang tidak terolah dengan baik menjadikannya suatu masalah karena berdasarkan data Kumparan (2019), rata-rata orang akan membuang tiga dari lima pakaian yang dibeli dalam waktu setahun. Padahal, pakaian zaman sekarang lebih banyak dibuat dari serat sintetis. Bila serat katun murni bisa terurai dalam waktu 2-5 bulan, maka serat kain sintetis baru bisa terurai di tanah selama 20-200 tahun. Menurut ulasan goodonyou.eco, untuk membuat 1 celana jeans dibutuhkan 3.781 liter air. Air sebanyak itu bisa digunakan untuk kebutuhan air minum harian 1.700 orang dewasa. Padahal dalam 1 tahun lebih dari 2 juta celana jeans yang diproduksi di seluruh dunia. Berdasarkan fakta tersebut, daur ulang kain menjadi salah satu pilihan yang dapat mengurangi pencemaran lingkungan sekaligus memberikan suatu nilai.

Masyarakat desa Munggugianti menghasilkan beberapa bentuk sampah rumah tangga yang sebagian masih dapat diolah dan memberikan nilai ekonomis. Salah satu bentuk sampah rumah tangga yang diolah pada kegiatan ini adalah kain perca. Proses penciptaan nilai dengan adanya kegiatan pendampingan sosial dapat membantu pemecahan masalah bersama. Kegiatan pengolahan limbah berupa kain ini dapat mengurangi pencemaran lingkungan dan membantu masyarakat dalam meningkatkan pendapatan. Hasil penelitian dari Idah (2020) menunjukkan bahwa dengan diberikan penyulisan mengenai pengelolaan sampah menjadi barang siap dijual memberikan kontribusi dalam meningkatnya pengetahuan dan pemahaman serta keterampilan para peserta didik.

Peserta kegiatan pengolahan limbah kain perca terdiri dari 11 orang usai produktif, 9 orang perempuan dan 2 orang laki - laki. Latar belakang pekerjaan dan pendidikan peserta beragam dan berbeda. Kegiatan ini diharapkan dapat menambah wawasan peserta dan ketermpalinan dalam pemanfaaatan limbah. Peserta dikenalkan teknik dasar dalam pengolahan limbah kain supaya limbah kain yang pada umumnya dibuang dan tidak digunakan, menjadi suatu benda yang memiliki nilai manfaat dan ekonomis. Di samping itu, kegiatan ini mendorong masyarakat untuk mengembangkan jiwa kewirausahaan. Dampak secara jangka panjang adalah berkurangnya tingkat pengangguran dan terbukanya usaha baru yang dapat dikembangkan oleh desa. 


\section{METODE}

Proses penciptaan nilai dengan adanya kegiatan pendampingan sosial pada mitra pengabdian masyarakat dilaksanakan dengan metode yang meliputi beberapa tahapan, yaitu:

a. Tahap Persiapan

Pada tahap ini, ketua dan tim pelaksana menentukan beberapa narasumber yang sesuai dengan bidang keahlian. Narasumber yang ditunjuk akan melakukan mentoring dan praktek kegiatan. Tiga narasumber ditentukan sesuai dengan kepakaran narasumber: dua narasumber dari bidang Fashion dan satu narasumber merupakan ekspertise dalam bidang mengolahan limbah. Pemilihan narasumber adalah berdasarkan pengalaman, keterampilan dan pengetahuan narasumber. Koordinasi dengan narasumber dilakukan melalui rapat. Rencana, pelaksanaan, dan capaian kegiatan juga didiskusikan pada tahap ini antara kedua belah pihak dan disesuaikan dengan kebutuhan mitra. Pemetaan kebutuhan narasumber dan peserta untuk pelatihan juga didiskusikan seperti: alat jahit, mesin jahit, contoh produk atau contoh pola dan bahan pendukung lainnya.

b. Tahap Pengadaan Kebutuhan

Pada tahap ini, kebutuhan peralatan dan perlengkapan menjahit seua dilengkapi sebelum pelaksanaan kegiatan dilakukan. Pemeriksaan ulang kepengkapan dan peralatan dilakukan setelah proses pengadaan. Beberapa peralatan disediakan sesuai dengan jumlah peserta untuk memperlancar proses kegiatan.

c. Tahap Pelatihan

Pelaksanaan kegiatan dilakukan secara langsung karena bersifat praktek kerja. Pelaksanaan pelatihan dilakukan selama 3 jam mulai dari pukul 09.00 - 12.00 WIB. Ketua, tim pelaksana, dan narasumber tiba di lokasi kegiatan pada 08.30 WIB. Ada mahasiswa yang ikut d dalam kegiatan ini untuk mendokumentasikan kegiatan. Pelaksanaan kegiatan dilaksanakan di Balai Desa Munggugianti dengan peserta sebanyak 11 orang. Urutan kegiatan dalam tahap pelatihan ini adalah:

1. Pengaturan tempat kerja karena menggunakan mesin jahit dan beberapa peralatan jahit.

2. Pembukaan, pengenalan narasumber dan penilaian produk. Tim pelaksana membuka kegiatan setelah peserta terkumpul dan mengenalkan tiga narasumber. Beberapa peserta membawa contoh produk yang telah dikerjakan di rumah dan diberi masukan oleh narasumber untuk dapat dikembangkan

3. Narasumber mulai memberikan dua contoh pola dasar, yaitu kotak dan segitiga. 
4. Peserta diminta untuk menggunting bahan yang telah dibawa mengikuti pola yang telah disediakan. Peralatan dan bahan mulai dibagikan.

5. Narasumber melakukan demonstrasi dan penjelasan mengenai pola dasar yang diberikan, yaitu mengenai teknik memotong kain dan menjahit pola quilting. Pola quilting merupakan teknik menjahit dengan cara menyatukan atau menggabungkan potongan kain perca sesuai dengan design yang diinginkan menjadi suatu kesatuan bagian yang indah dan berpola. Kotak dan segitiga merupakan pola yang sangat dasar dalam teknik ini.

6. Pola yang telah dipotong kemudian disusun supaya membentuk pola tertentu. Bahan yang dibawa oleh tim pelaksana dan warga cukup beragam sehingga motif yang disusun berwarna warni.

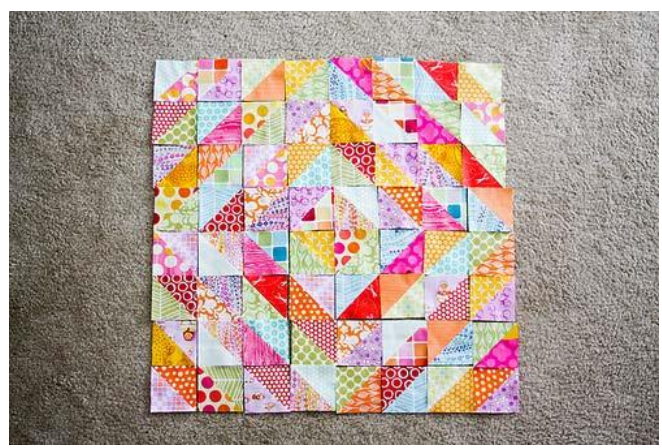

Gambar 1. Contoh Pola

7. Pola yang telah disusun kemudian disatukan dengan menggunakan jarum pentul terlebih dahulu supaya tidak berubah saat akan dijahit.

8. Narasumber melakukan proses demonstrasi menjahit kain yang telah disusun dan disatukan sementara. Tim panitia menyediakan dua jenis mesin jahit yang memiliki pergerakan cepat dan lambat. Peserta melakukan proses menjahit secara bergantian. Ketepatan dan proses ini membutuhkan keterampilan tersendiri. Beberapa peserta yang sudah terbiasa dengan alat jahit menggunakan mesin jahit pergerakan cepat. Sebagian lain menggunakan mesin jahit pergerakan lambat karena masih dalam tahap pengenalan dan uji coba. Dalam proses ini, antusias peserta tinggi. Saat menemukan kesulitan dengan memotong ataupun dengan alat jahit, peserta langsung bertanya dan mengulang proses jika ada kesalahan 


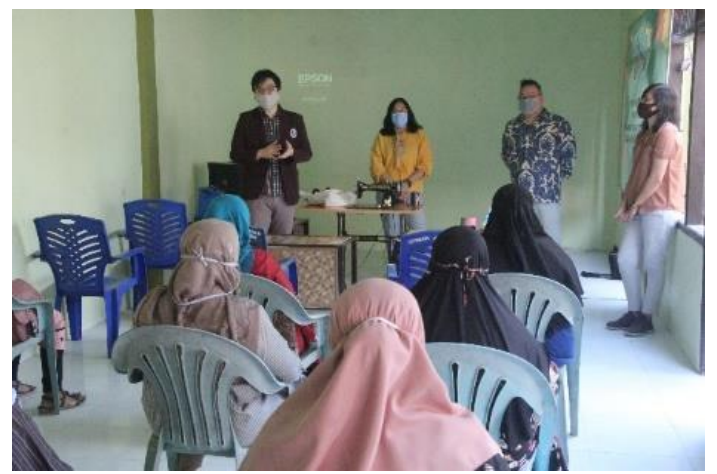

Gambar 2. Pelaksanaan Kegiatan

9. Keseluhan potongan kain disusun dan dijahit menjadi satu kain besar yang utuh. Narasumber memberikan masukan dan arahan untuk tahapan selanjutnya dalam membuat model menjadi tas ataupun bentuk yang diinginkan.

10. Penjelasan tambahan mengenai berbagai macam bahan yang dapat dan tidak dapat disetrika serta pengetahuan tentang pencucian, karena keberagaman kain yang memungkinkan luntur saat dicuci.

11. Narasumber memberikan contoh produk jadi kepada peserta dengan harapan peserta dapat mengembangkan pola dasar menjadi sebuah produk ekonomis yang memiliki nilai jual.

12. Praktek pengembangan materi. Setelah pemberian materi dan proses praktek berlangsung, tim membagi kelompok peserta dan membagikan modal untuk dapat dibelanjakan peralatan kebutuhan dan pada pertemuan selanjutnya kelompok dapat melakukan presentasi hasil kegiatan. Tim penyelenggara juga mengarahkan peserta untuk dapat melakukan pelatihann secara mandiri karena mesin jahit ditinggalkan di ruang belajar di balai desa. Peserta dapat sewaktu - waktu menggunakan alat jahit tersebut

d. Tahap Evaluasi

Tahap terakhir dalam metode pelaksaan kegiatan ini adalah evaluasi. Ketua pelaksana, tim dan narasumber melakukan proses evaluasi setelah kegiatan selesai. Dalam tahap ini, kendala, proses dan masalah teknis didiskusikan. Tim pelaksana selanjutnya akan melakukan proses evaluasi dan perbaikan supaya tidak terjadi lagi gangguan yang sama dalam proses selanjutnya

\section{HASIL DAN PEMBAHASAN}

Pada tahap persiapan, tim pelaksana memutuskan bahwa pelaksanaan kegiatan pengolahan limbah kain perca dilakukan di Balai desa Munggugianti dengan peserta 11 orang warga desa. Pelaksanaan kegiatan dilakukan dengan tepat waktu dan sesuai dengan tema yang telah disampaikan. pada pelaksanaannya, melibatkan beberapa narasumber yang memiliki latar belakang fashion design. 
Pada tahap persiapan kebutuhan, alat bantu dan alat penunjang kegiatan dipersiapkan oleh tim penyelenggara dengan lengkap dan sesuai dengan kebutuhan. Alat penunjang lain seperti proyektor, sound system dan LCD juga disediakan seupaya menyampaian materi (dengan contoh slide dan video dengan suara) dapat dengan maksimal ditangkap oleh peserta. Kebutuhan lain seperti tersedianya konsumsi dan minum juga disediakan oleh tim pelaksana.

Pada tahap pelatihan, dalam proses penyampaian materi dan praktek kerja, pendampingan selalu diberikan supaya kesalahan ataupun peserta tidak melewatkan materi. Dalam pelaksanaan kegiatan ini, tiga narasumber dihadirkan dan dipilih sesuai dengan topik, pengalaman, keterampilan dan kebutuhan. Pada masa pandemi Covid-19 ini, protokol kesehatan juga menjadi perhatian bersama, pihak tim pelaksana selalu menyediakan masker dan hand sanitizer. Pihak peserta juga dengan kesadaran selalu datang dengan menggunakan masker. Selama kegiatan berlangsung sampai dengan selesai, masker selalu digunakan.

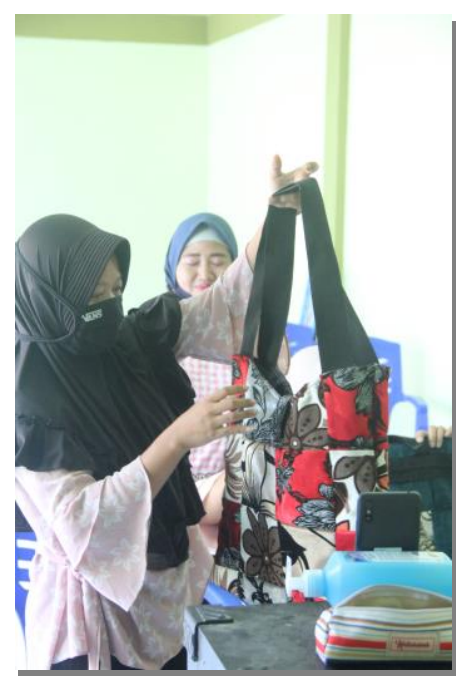

Gambar 3. Pembuatan purwarupa

Materi mengenalan dasar pendauran ulang kain perca merupakan salah satu kegiatan dari rangkaian panjang proses pelatihan pengolahan limbah. Mengenalkan pemotongan pola, penggunaan mesin jahit hingga pembuatan prototype produk yang dilakukan dalam kegiatan ini merupakan langkah awal pembuatan rancangan produk. Dalam proses ini, antusias dan inisiatif peserta sangat tinggi. Saat menemukan kesulitan dengan memotong ataupun dengan alat jahit, peserta langsung bertanya pada narasumber dan mengulang proses jika ada kesalahan. 


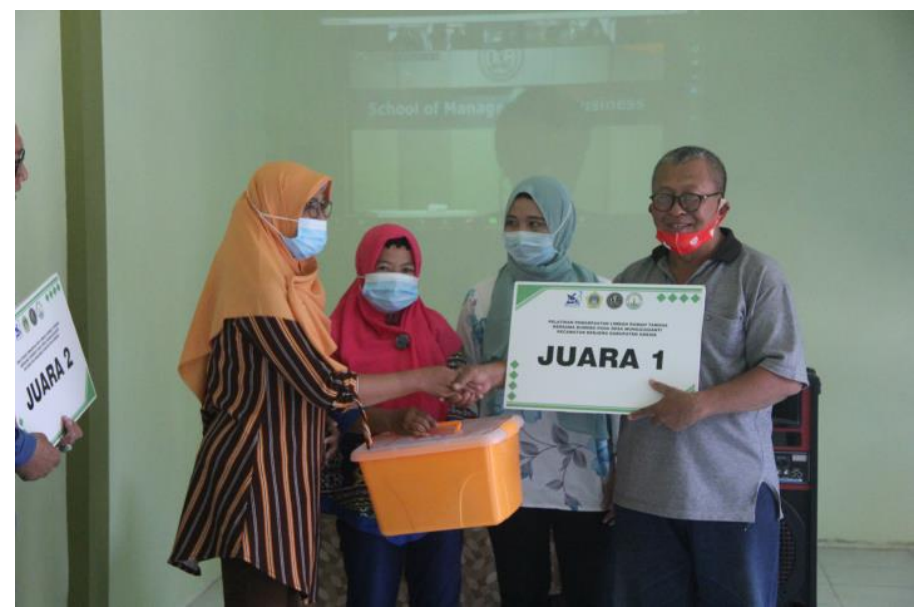

Gambar 4. Apresiasi atas performa peserta

Hasil dari tahap terakir yaitu evaluasi menunjukkan bahwa materi yang diajarkan dapat diterima oleh pada peserta. Dibuktikan dengan hasil karya mereka yang siap untuk dipasarkan. Kendala dan teknis dalam pelaksanaan acara juga dirasa tidak ada yang bersifat material.

\section{KESIMPULAN}

Simpulan yang diperoleh dari pelaksanaan program pengabdian masyarakat "Program Daur Ulang Limbah Kain Perca di Desa Munggugianti, Gresik, Jawa Timur” adalah:

1. Tingkat partisipasi yang tinggi dibuktikan dengan sejak pertemuan 1 hingga terakhir, ke 11 peserta mengikuti semua tahapan pelatihan dari mitra program kegiatan pengabdian kepada masyarakat yang menberikan dampak positif pengurangan limbah dan penambahan nilai ekonomis.

2. Keterampilan bagi peserta bertambah

3. Narasumber yang sesuai dengan kebutuhan, memiliki keterampilan dan pengetahuan terhadap proyek mempermudah peserta memperoleh wawasan

\section{DAFTAR PUSTAKA}

Amnah \& Sari, Novita. (2015). Peningkatan Keterampilan \& Ekonomi Ibu-Ibu PKK Melalui Pengolahan Limbah Kain (Perca) Di Kelurahan Way Kandis. Jurnal Teknologi Informasi Dan Bisnis Pengabdian Masyarakat Darmajaya. 1(2). 1-11

Devanti, Yeni Mardiyana. (2017) Pemanfaatan Limbah Konveksi Untuk Meningkatkan Pendapatan Rumah Tangga Miskin. Jurnal Pengabdian Masyarakat IPTEKS. 2(1). 51-56.

Dewi, Novi Ayu Kristiana. et al. (2020). Pelatihan Keterampilan Kain Perca Untuk Mengurangi Limbah Anorganik. Sasambo: Jurnal Abdimas. 2(2). 49-56.

Dewi, Ratih Kusuma. et al. (2017). Pelatihan Pembuatan Bedcover Kaca(Kain Perca) Untuk Bekal Wirausaha Di Panti Asuhan Bina Insani Ngawi. Jurnal Pengabdian Pada Masyarakat. 2(2). $57-$ 61. 
Fahriana, Nina. et al. (2017). Sosialisasi Dan Aplikasi Penambahan Nilai Kain Perca Dengan Menggunakan Metode Quilting Di Gampong Teungoh, Keamatan Langsa Kota, Kola Langsa. Seminar Nasional Teknik Industri. 178-183.

Halim, Hasmar. et al. (2019). Upaya Peningatan Kesejahteraan Keluarga Melalui Pemanfaatan Bahan Daur Ulang Limbah Di Desa Manimbahoi Kabupaten Gowa. Prosiding Seminar Nasional Penelitian \& Pengabdian Kepada Masyarakat. 197-202.

Idah, Yusyida Munsa Idah. (2020). Edukasi Pengelolaan Sampah melalui Pelatihan Pengelolaan Limbah Kain Perca Menjadi tas Belanja Ramah Lingkungan. Jurnal Pengabdiam Mitra Masyarakat. 2(1). 1-8.

Rosdiana, Aliva. (2018). Pelatihan Pemanfaatan Kain Perca Sebagai Ape Pillow Doll Untuk Pembelajaran Anak Usia Dini Di Kuwasen Jepara. Journal of Dedicators Community UNISNU. 3(1). 1-7.

Rosmiati, Eros. et al. (2018). Peningkatan Produk Cinderamata Dari Kain Perca Untuk Menambah Penghasilan Keluarga Di Kelurahan Bambu Apus, Jakarta Timur. Jurnal Pelayanan dan Pengabdian masyarakat. 2(2). 43-60

Septiawati, Rani. et al. (2019). Pemanfaatan Limbah Kain Perca Sebagai Alternatif Peluang Usaha. Journal Of Community Service. 3(1). 1-8.

Wisesa, Toufiq Panji \& Nugraha, Hadi. (2015). Pemanfaatan Limbah Kain Batik Untuk Pengembangan Produk Aksesoris Fashion. Jurnal Universitas Pembangungan Jaya. 2(2). 70-86 